\title{
THE COMPLEX NATURE OF POTENTIAL ARCHITECTURAL FUTURES
}

\section{A B S T R A C T}

Architecture is changing, complying with innovations and technological advances of designing tools and methodologies. Investigating and defining the space, whatsoever, still remains its basic task. Technology available to architects has revolutionized the management of the morphogenetic procedure through new modeling techniques, formal speculation and its enrichment with artistic intuition. It has encouraged architects to experiment on the structure and morphological attributes of natural systems and organic as well as inorganic forms and has seriously affected the correspondent spatial proposals. New concepts, introduced in the architectural discussion and contemporary design-driven research suggesting extraordinary examples of spatial arrangements, speak of a completely new architectural reality. Approached through a holistic and interdisciplinary spectrum and still confined inside Schools of architecture, this new architecture measures its future potential and chances of actual application.
Anastasios Tellios

Aristotle University of Thessaloniki
KEY WORDS

BIOLOGY-DRIVEN DESIGN

NATURAL ADAPTATION

GENERATIVE ARCHITECTURE

ARCHITECTURAL NARRATIVES

SPATIAL INVESTIGATION

EMERGENCE 


\section{INTRODUCTION}

The theme researched in this article is addressing the issues referring to the once again defined relation between architecture and innovative technology. As this relation grows deeper and is already irreversible, a certain degree of intellectual as well as physical osmosis occurs between the worlds of technology and architecture. Architecture absorbs the information technology tools and methodologies and gradually begins to digest and internalize them. There is an evident shift from humanities towards technology and this is the outcome of the osmosis mentioned above. The proof for this underlying procedure is provided and documented within the studies' curricula of Schools of Architecture and relevant research institutes worldwide.

The prevailing theoretical frame suggests a general consensus and encouraging of the development and enrichment of new technologies and advanced digital design techniques. This is the current state of art for the education and training of architects and this should be clearly stated. Architecture, though, has -and should- never have resigned from being a space-investigating act. Its main task is conception, designing and production of space. The definition of space in this context is that of space being the vessel of human activity and social interaction.

There is a set of values of architecture that have defined and followed architecture so far, such as permanence, solidity, stability and clarity. These values have guided the architect's practice almost forever, but under a prism of innovation, they do not seem to be valid anymore. Furthermore, there is a sometimes light-hearted feeling among circles of criticism when almost renouncing them as flat and narrow-minded. These values, though, have never been a flat projection of a similarly flat internal discussion. They have been theoretical platforms, proved and tested for centuries. Each time they were closely tied to the certain, existing technological level that prevailed and supported civilization each time.

Since technology constantly evolves and re-shapes the cultural construct, as we know it in an unprecedented way, architecture inevitably has to follow and re-adjust itself responsively. This kind of procedure has been happening forever and still does. What should be pointed out, though, is that when it comes to architecture, it happens with a certain phase difference, compared to the technological advances. This phase difference has to do with architecture's special features, which are related to architecture's apparent geometry, its mass and solidity, its very physicality as essential component of the built 
environment. Therefore, a certain amount of criticism that this 'old school' approach is receiving is largely a projection of forces of intellectual inertia and not an internal or intrinsic intellectual stubbornness of architecture. And definitely it does not imply any possible inadequacy of the architectural intellect per se. Architecture just needs time to understand any new status and adapt and comply with the new rules set each time.

\section{A RECURRING AGENDA OF QUESTIONS}

What stands before us, as architects, is a promising, yet only almost new understanding of the space-defining procedure. This new understanding of the act of architecture, allows the re-emergence of a typical array of issues. These issues have belonged to architecture's agenda for centuries. They address a repertoire of quasi-classical bi-poles, such as old-new, natural-artificial, etc. The validity of these bi-poles, when applied to architecture, presupposes also the validity of all the corresponding hybrids between the poles each time.

According to a certain line of thinkers, the various parameters of architecture can still successfully be defined by G. Broadbent's four 'deep structures' as an explanatory scheme for architecture'. This scheme includes the functional factor (architecture as container of human activity), the aesthetic factor (architecture as a symbolic object), the ecological factor (architecture as the converter of natural resources) and the physical factor (architecture as interacting within the built world). Previous and so far valid definitions of architecture have been considering these parameters as separate entities to be judged autonomously.

The late and simultaneous innovations of architecture and technology have urged that the architectural discussion addresses the architectural procedure as a whole. There are strong unifying elements acting as catalysts today. These unifying elements ultimately describe the way architecture is discussed, designed, scripted and fabricated today, not necessarily following this order. They incorporate two substantial, core issues, questions that once again emerge in the architectural discussion. The first question is about how to handle complexity, and the second question has to do with what to do with nature.

\section{Handling complexity}

Complexity has been the object of the architectural thinking during various times in the past. During the past years, following the structural waves of modernism, post-modern theorists as well as the avant-garde of the time have attempted to decipher complexity and then incorporate it in architecture in 
a coherent manner. This has not always been done effectively, even though at the time, it has received positive public welcome. Robert Venturi, during his mature, post-modern culmination has tried to address complexity when designing his "Vanna Venturi House'2. He presented an obvious overlap of elements running throughout the design procedure, from the organization of space to elaboration of the plans and articulation of the elevations. Some decades later, Frank Gehry offers a more alternative version of complexity in his iconic Guggenheim Museum in Bilbao. With an underlying theoretical discussion of de-construction of the time, Gehry presents an unprecedented spatial definition of a complex architecture. Both approaches have had a deep influence in architecture and they are already distinctive moments of modern architectural history. As interpretations of complexity, characteristic of specific and defined architectural genres, they are educated, eloquent and strict. Still, though, they seem rather confined in their strictness and offer only a faceted image of complexity and its dynamics.

\section{Dealing with nature}

Compared to these examples, natural systems that possess and incorporate complexity in their entirety, act in a different way. The ancient city of KharaKhoto, once a prosperous and sophisticated urban system, has been operating as a city for centuries. When the regional climate changed, the local ecology collapsed $^{3}$. Ecologies shifted and changed and a more flexible natural system, more adaptive to complexity prevailed. Sand dunes now cover the ancient city, providing a natural topography of waving sand structures. The mere naivety of this example of natural prevalence following an almost Darwinian procedure projects a non-educated, yet efficient spatial action. The same kind of natural wisdom has been derived through Antonio Gaudi's experiments with sacks of sand and the spatial distribution of their weight load. A funicular, physical model hanging from the ceiling incorporates an automatic structural scheme and a spontaneous natural behavior in the field of gravity. It was initially done by Gaudi himself for the Colonia Güell church and then reproduced by Frei Otto and Jan Molema for the Sagrada Familia. Gaudi's extraordinary architecture achieved in his Sagrada Familia church is indeed a creative mutation of nature's wisdom in the artificial world. It speaks of a successful deal with nature and the act of learning from it.

Pointing out these two issues is a direct cross-reference back to the spaceinvestigating task of architecture, as stated in the beginning. Once again, architecture has to deal with complexity and its relation with nature, following a constantly recurring agenda. 


\section{OBSERVATIONS ON A CHANGING CONDITION}

The main focus of this research is to investigate advanced design techniques used by architects when designing space and human-made environment in all its possible scales. Groundbreaking developments in digital technology during the previous decade have completely reshaped the design culture and redefined architecture's routines and methodologies. Given these developments, the research will study the implications on five fields. All of them are territories already affected by the architectural procedure. That which is distinguishing about this case is the deeply interdisciplinary and tolerant character of the recent paradigm. The investigation will focus on the relationship between the procedure of architecture and a strongly established set of links with nature, technology, art, environment and society. There is an evident research 'suspicion', which needs to be discovered, disclosed or invented. It has to do with the forthcoming shift of paradigm towards a holistic, catholic approach, towards a procedure of an 'emerging' built environment'.

\section{Architecture as a space-investigating act}

Investigating and defining the space and the produced morphology has been the main task of architecture. The starting point of this research is the belief that space is the dominant feature of the social life of humans, but also, perhaps one of the most important cultural expressions of the overall civilization of each era. A systematic investigation and further analysis of the spatial phenomenon, therefore, is always necessary for the researching architect.

Architecture is an eminent hybrid of both science and art. It is negotiating spatial attributes which thus must be the main focus of a research referring to the most influential disciplines towards the achievement of human sustainability. Even as a spatial exploratory action, holding great epistemological and research strength, architecture is responsible for the formulation of clear thoughts, principles and theories about the meaning, the structure and the importance of space. Therefore, along with economic, social, ecological factors and being affected by so many other developments, the issue of space is revealed as a research setting. From this point of view, space is not exclusively associated with the material objects' meaning and identification, or mere understanding of them through a theoretical, philosophical and intellectual approach, but with a broader cultural rationale. Research about space concerns the entire way of contemporary living, all built architectural elements and their environmental performance. 


\section{Nature as a source for architectural reference}

The connection between the built and the natural environment is a complicate set of arrangements and implications. All these issues are directly reflected in the relation between architecture and nature. This relation needs to be examined through a multidisciplinary convergence of a wide array of scientific disciplines. Nature and its structures have been a constant reference source for architects throughout the architectural history, in the space-conceiving procedure and defining of structural articulation. Until now, though, it has mainly been confined to a visual, artistic level, looking to natural forms of life, including both organic (biological, vegetal, etc.) and inorganic (geological patterns, fluid movements, etc.) structural units.

These thematic starting points remain the same: the sea with its flora and fauna, the topographic and geological concepts, the forms and materials of forests and of plants, anthropomorphic and zoomorphic approaches, or even scent, and climate, the relationship between nature and the various design disciplines has intensified in the recent years. This is maybe due to the enrichment of contemporary discourse with concepts derived from even more advanced scientific disciplines, such as biotechnology and bioengineering. The 'model of nature, thus, with its forms, structures, and organizing principles, does not only inspire the widest range of concepts and design processes, but also can be expressed in a broader spectrum of forms and functions, towards architectural, engineering and construction applications.

There seems to be transitions concerning the way architects understand the design procedure. There is an intricate interchange of ideas between the disciplines of biology, physics, chemistry and mathematics, as they are separate, almost discrete but actually overlapping when related to architectural design. In those cases, boundaries between them are indeterminate and they strongly affect the contemporary architectural theory and practice.

This suggests an innovative and prolific approach on design modeling issues, focused on the form-finding procedure. The evident 'architecture' of all natural forms is identified in their arrangement of materials in space and over time. It emerges from the dynamic interaction of energy and material within complex systems. This discloses a groundbreaking direction for architects and introduces possible future tasks for the discipline of architecture. A wide range of form-finding techniques and the corresponding research methodology are 
of great importance when attempting to define and imitate the irregularity, the strength and the efficiency in biological structures. This encourages the invention of special architectural structures, by employing bio-mimetic growing systems and the geometry of advanced mathematics used in the space-modeling routines.

\section{Advanced digital design: methods, procedures and strategies}

As mentioned above, the rapid evolution of digital technology available to architects and the management of the morphogenetic procedure through digital modeling techniques, has encouraged architects to experiment on the structure and the morphological attributes of natural systems. These evolutions have facilitated the establishment of innovative, advanced design principles. We can now take advantage of their, until today unforeseen, capacity of integrating evolutionary computation, generative computation, physical environment modeling techniques, experimental strategies in the representation of threedimensional space as well as prototype production methodologies.

Furthermore, it has enabled the assignment of a new, compelling goal to be achieved. This goal is related to the documentation and the instrumentalisation of natural processes of evolution and growth. Its obvious benefit is enrichment of architectural modeling techniques, clarification of the essential features of emergence and combining these within a computational framework. The final outcome is the capability of developing generative design tools and conception and ultimate production of complex and adaptive architectural forms.

The attempt of a spatial expression or integration of similar advances or/ and perceptions presupposes a wider association of architecture with digital technology sciences. An urgent investigation that needs to be implemented includes examination of the potential revolutionary synergy between architecture, artificial intelligence, information theory, virtuality, cyberspace, climate studies, material science, bioengineering and nanotechnology. This covers a so-called 'digital pantheon', having a strong impact on architecture and the future paradigm of the man-made environments.

\section{Spatial exploration through artistic intuition}

Artistic intuition, and art in general, has been the medium for introducing revolutionary ideas to broader audiences, through its established freedom of expression, and the enormous capacity to digest the contemporary proceedings. 
Furthermore, it has historically been documented that specific ideas, initially expressed through artworks, were the essential manifestoes which, after a period of maturity and broader acceptance, were followed by the corresponding scientific or other developments, concluding to sometimes vital results for the entire humanity.

When it refers to the field of architecture, the art of the 'architectural drawing', is mainly considered to be the motive force and the preliminary stage of a later, more precise, developed architectural concept. Consequently, this familiar vehicle is vital for architects towards their attempt to experiment with form, structure and space. A deep analysis of such a wide range of artistic forms of expression and their potentiality is considered necessary for the research.

These notions stand in straight relationship with a broader and rather creative approach of advanced design tools and architectural production methodologies. They can be perceived as visions of contemporary intelligence and augmented reality. A novel blend of digital and analogue techniques is often the case for artworks created under this context. The way art uses this experimental combination of creative tools offers an alternative mode of digital practice. It shows how creators and consequently architects could potentially absorb the latest digital techniques, inherent to mathematical, geometrical and informational practices, while still embracing the artistic poetics and the knowledge of cultural traditions. This procedure constantly pushes further the very boundaries of creativity and expression and intuition, inherent to human personality.

The main argument proposed here is maturing of our understanding of the digital space, the notion that we cannot any longer rely completely, nor solely on the computer, nor on the 'talented hand'. The research of these issues emphasizes the importance of overlaying a mastery of digital techniques with a nuanced and developed aesthetic sensibility. The goal here is the production of unprecedented architectural effects. Artistically mastered architectural images seem to be the theoretical and virtual manifestations that could 'speak' for new architectural ideas.

\section{Inhabiting the built environment and challenging of scales}

The main effect of this approach as a whole, seems to be rather a considerable change of the degree of human intervention in nature when designing the built environment. The scientific advances in both micro and macro scale, provide 
the idea of a completely manipulative nature. This enables architecture to regulate its collective efficiency and thrive in a variety of, so far considered as marginal, territories, while canceling any limitations concerning possible range of design scales. This culture encourages cross-scale approaches, now boldly varying from nano-objects to landscapes, in contrast to , until recently, limited scale of architectural interventions, ranging from the scale of the industrial product design to the scale of urban design.

The world seems to be within the horizon of systemic changes that will cascade through all the systems of nature and civilization. It is obvious that human structures and their networks will expand and develop, strongly coupled with the dynamic changes within which they were situated. This has direct implications on the expanding urban environments. Architecture will be challenged to actively conceive and produce all new internal and external environmental arrangements. The built urban environment and its immediate surroundings are expected to become infused and converged. Such a thought refers to an architecture beyond classic environmental entanglements that renders the thresholds between artificial and natural really blurred.

In the next decades the majority of human population is expected to live in cities. This undeniable fact renders the urban environment as a space of great importance. Architecture is challenged to constantly redefine dependencies between natural spaces and human-made space. Architects, as designers of space, will have to address the task of the improvement of social, political, financial and architectural conditions that define our urban culture. These are issues that are strongly connected to our everyday lives, as they influence the social interaction and the way people inhabit contemporary cities.

The future built environment of the new cities will be conceived with specific spatial attributes connected to behavior, self-organization, and dynamics of differentiation and integration, notions emerging from the repetition and interaction of specific rules derived from natural phenomena. Extensive study and experimentation in this direction could offer a comprehensive approach towards development of a computational simulations of a living architecture through the use of natural micro- and macro-dynamics in advanced architectural ways, methodologies and materials. 


\section{RESEARCH BY DESIGN AND STUDIO INVESTIGATIONS}

The intellectual frame placed by previous observations is part of the agenda of a design studio at the School of Architecture of Aristotle University of Thessaloniki, Greece. The design studio is called '2S1 62: Spatial investigations and the limits of design'. A further series of Diploma projects and Diploma theoretical researches is organized and implemented under this scheme.

The object of the research conducted is related to the procedure of architectural design and investigation of its origins and its limits. As stated in the studio's curriculum, it attempts to connect architectural design, as a deep, creative procedure with the broad fields of innovation, the study of structures (biological, technological, etc.), the scientific observation (microscopic, molecular, macroscopic, etc.), as well as other scientific and creative fields, using advanced technologies for digital design and spatial representation. The aim is to understand the dynamics of space and its qualities, challenging of established building schemes and the experimental process of complex and sometimes unexpected alternative functional programs. Students attempt to articulate proposals of innovative spatial situations through comprehensive, synthetic architectural narratives.

Particular emphasis is placed on encouraging development of personal design vocabularies, portraying flexibility and resourcefulness in responding to complex spatial requirements. The studio's design direction can be coded in the following: the use of advanced design techniques, the employment of spatial narratives and a complete freedom of expressive means. The studio always tries to look at a 'big picture', with architecture being a part of a broader environment, physical and intellectual.

A naturally inspired and adaptive architecture as a notion but also as a physical incorporation of life is placed under focus. The methodology as to design a 'living' piece of spatial arrangement, the social interaction of biologicallydriven design elements and the adaptation of the humans within the physical environment are design approaches successfully implemented in the 'research by design' frame. 'Living' qualities of the proposed architecture have a certain connection with the human as an entity, its scale, its needs, its ethics let us say, and its very human features. It is, though, quite far from metabolistic approaches as they have appeared in past decades and were represented by important architects in the " $60 \mathrm{~s}$ and ' $70 \mathrm{~s}$. What really is investigated here is a 
new relation with the physical environment. The architect's work is considered as a procedure articulated with the physical environment and eventually being part of it. The physical environment does not stand outside the frame. It is not a sterilized entity besides architecture but an organic element within the very core of architecture.

Three different design approaches will be presented. Apart from their innovative architectonics, they seem to address a broader agenda covering most of the observations presented in the previous section and incorporating formal, social and environmental parameters. The research implemented is done through a specific trend of 'design speculation'4 using advanced tools and the use of spatial narratives to support the presented schemes.

\section{Birth ponds, in_vitro/arch}

The project investigates the possibility of designing the 'body' of architecture, thus the ability of a formal, spatial and structural language not just to imitate a physical (biological) body, but to generate a physical presence through 'reading' biology's generative techniques ${ }^{5}$. The designed spatial device is a not a smart skin or surface but an entire spatial organ. The project addresses the issue of geotropism, thus the ability of plants to respond to gravity and the circles of life involved. Architecture is considered as a parasite to nature and not vice versa. What is investigated here is the possibility of a form to evolve, mutate and grow, each time adjusting itself to certain functional and spatial needs. Form-generating natural policies are replacing the, sometimes infertile, form-finding parametric techniques. The aim is to find ways to incorporate biological techniques and mechanisms into architectural design procedures. (Figure 1)

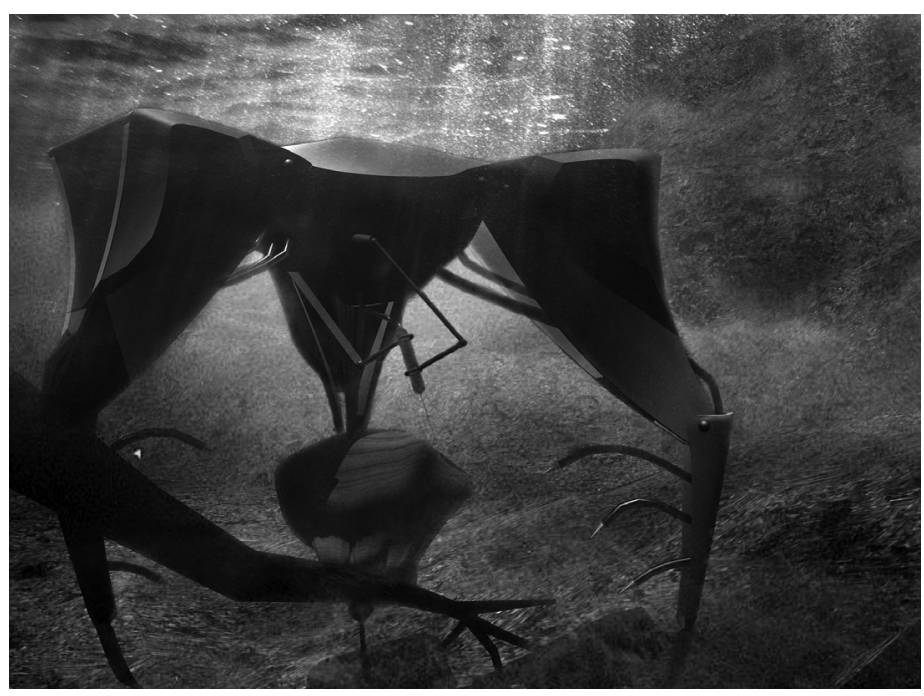

Figure 1 Birth ponds, in_vitro/arch: Mechanism for a living architecture 
The specific project is about the design of ephemeral constructions. Placed in between the boundaries of science fiction and reality, it attempts to introduce a 'living' parameter in architectural design. The creation of form emerges from the controlled development, growth and eventually deterioration of plant mass, the -genetically mutated- cells which are not able to follow the law of gravitism. By suggesting a continuously changeable process, instead of a final outcome, it investigates the dynamics of space and its qualities, to the point where the significance of the 'circle of life' is not only connected to the users along with their activities, but also to the 'containers' of life. The designed product does not imitate a physical, biological body. Instead, the project focuses on attaining and maybe rationalizing a structural, morphological, formal genius found in nature. This genius is ultimately transcribed into architectural design.

\section{Spatial Cochleas}

This project attempts to research the potential of choreographing the behavior of architecture through the social interaction of a spatial, biologically-driven device with the everyday lives of humans ${ }^{6}$. The project uses the given space and architecture. It researches the capacity to create an open-source system, able to absorb and physically respond to social stimuli and re-adjust itself. The designed mechanism is closely related to the behavior of people and elements of architecture.

The scientific search of the project is initiated by the ability of the human auditory system to distinguish specific sound frequencies within a wide frequency range. This property is explained by industry psychophysics and theories of "Auditory Scene Analysis"7. Using similar sets of theories, the protocol of a biotropic organism is articulated. (Figure 2)

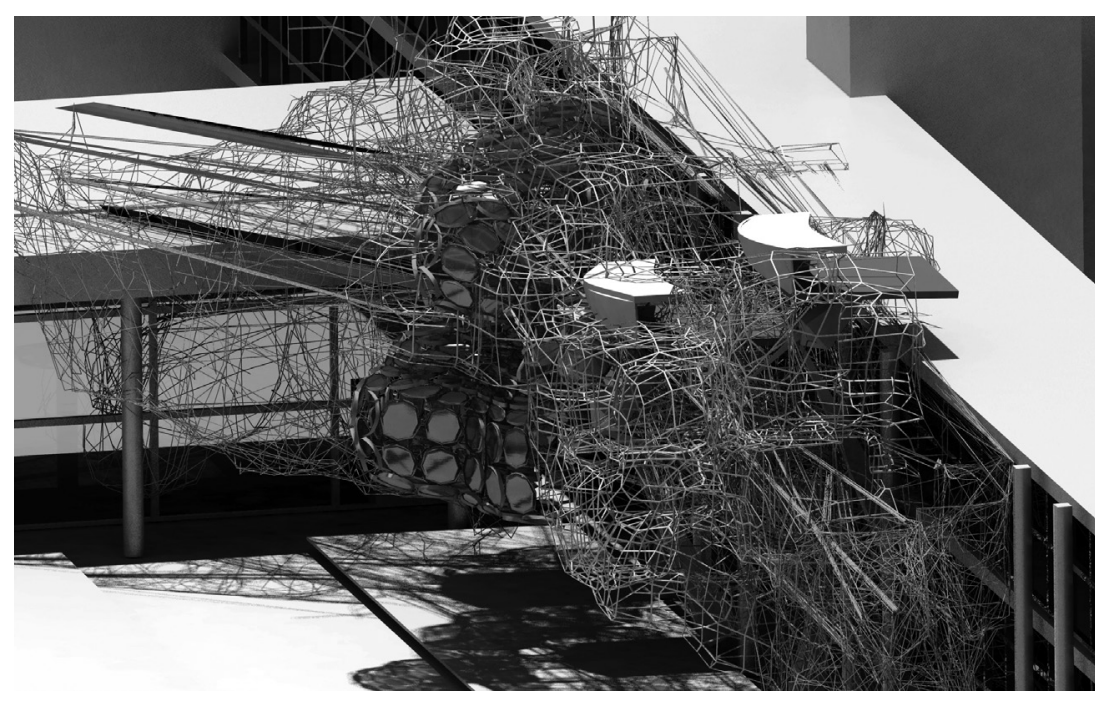

Figure 2 Spatial Cochleas: A parasitic mechanism 
The Cochlea is a parasitic mechanism, which represents spatial mapping of frequencies inside the environment that it resides in and 'feeds' on. By using certain hierarchical procedures the mechanism evolves and allows for direct modification of functionality from its users through an 'open-source' language. The Cochlea interferes in the social habits of humans occupying space. It is present in their places of gathering and their passages. Moving and standing, are characterized by different architectural qualities. The Cochlea reads these human habits, and their distinct frequencies. It then responds and re-adjusts its very physical presence and the size and position of its elements.

\section{Inhabiting fragile territories: a little story for a little house}

This diploma design research project speculates about generating of spatial hybrids, fulfillment of a functional program and their adaptation in a physical surrounding ${ }^{8}$. Natural elements are suggested to inspire the generation of key architectural components that will, eventually lead to the composition of a new man-built environment and territory. The design scheme involves an essential symbiotic narrative. This is the basic architectural concept of the 'inhabitation' of nature. This procedure is supposed to enable and activate space so as to deliver and facilitate specific human life and activity.

Initially this project was worked out using actual tactile techniques, molding clay and plaster using handcraft. A certain speculation was conducted as to find a way to frame human, visceral wisdom, delivered instinctively onto matter by the movement of the hand's muscle while molding clay models, and interacting with nature using manual labor. Then the physical result was once again examined and re-articulated using digital tools. This allowed for the speculation of a constantly evolving and expanding formal condition, where apart from measurable elements, other nonmaterial qualities were incorporated into the digital model. (Figure 3)

This all happens within the boundaries of a speculative, interactive and nonlinear relationship. As the architectural product emerges and is produced by the elements of the landscape, at the same time it actively reproduces that very landscape and to a certain extent gives physical 'birth' to it. An organic 'fight' takes place between materials and human actions. The project speculates on ways of a direct domestication of nature, and a 'gentle' incorporation to the maximum possible extent. Human existence depends materially on the surrounding territory and at the same time natural elements depend essentially on human action, craft and labor. (Figure 4) 


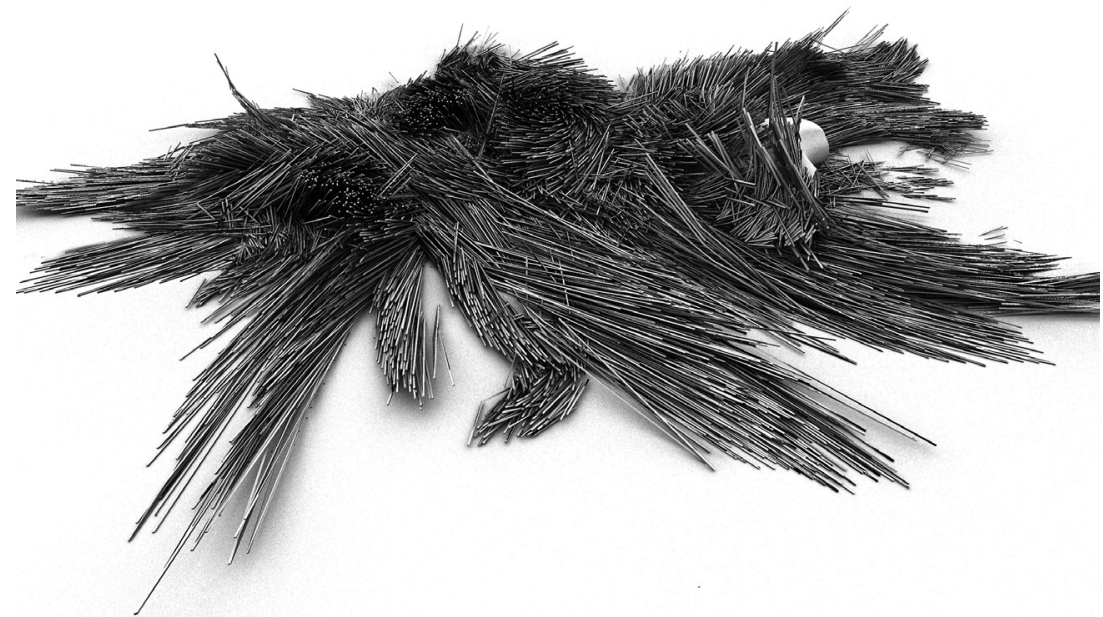

Figure 3 Inhabiting fragile territories: Speculative, non-linear landscapes

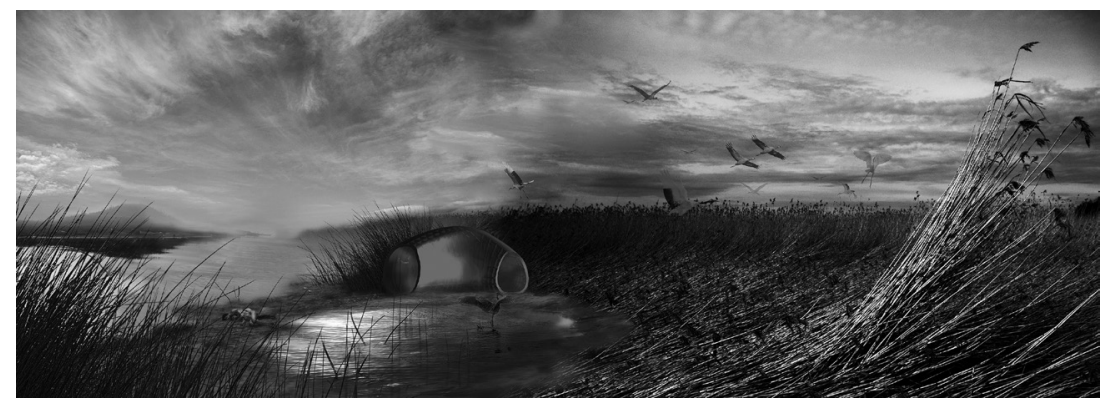

Figure 4 Inhabiting fragile territories: Emotional and experiential digital space 
What is subconsciously investigated here is a series of notions, so far only superficially touched by 'digital architecture's' discussion: the insuperable, the imaginary, the mysterious, the emotional, even the illogical, the experiential or the subconscious and their possible projection within a virtual, digital space and world. Additionally, a fresh environmental agenda is hereby presented and supported, which is far from existing 'green' and sometimes insufficient, commercial architectural solutions.

\section{CONCEPTS FOR A POSSIBLE SHIFT OF PARADIGM}

As mentioned before, there is an underlying holistic frame, which holds the research suspicion of a changing paradigm in architectural design. New concepts are possibly about to be introduced in architecture and the world of structures. Innovative spatial proposals, as described previously, are documented almost exclusively in experimental architectures designed in schools of architecture. The question whether they will have real application in the constructed world is one of the issues to be addressed.

\section{Architecture of emergence}

So far, the understanding of architecture was based on the premise that architectural structures are singular and fixed. Architecture is supposed to be clearly defined by its surrounding context, even if sometimes it is actually integrated and its boundaries are carefully smoothened. This is a mono-directional interpretation of architecture. The paradigm of emergence suggests that an opposite direction of thought is possible and true. The notion of 'emergence' attempts to clarify the process by which new and coherent structures, patterns and properties 'emerge' from within complex systems'. Architectural structures can be complex energy and material systems that have a specific lifespan. They can exist as parts of active systems, and develop in an evolutionary way. The paradigm of emergence introduces a radical point of view for understanding the way in which architecture is conceived, designed and produced. It demonstrates the interrelationship of concepts such as self-organization with the latest digital technologies in design, manufacturing and construction.

Consequently, the new concept of emergence, in accordance with the well established parametric morphogenetic mechanisms, generative-component design theories and the correspondent spatial proposals, create a new vision for architectural thinking. A vision that refers to morphology emergence, 
more as result of interplay between dynamic systems and less as an architect's absolute intention. Furthermore, this trend focuses on the investigation of an ultimately liberated formal vocabulary, based on the use of computationally accuracy and its capacity to produce non-standard complicated geometries and scale-free landscapes.

Bio-sciences out of the $1 a b$

As seen previously, a big amount of innovative projects are related to a broad array of bio-sciences that have just gotten out of the lab. Biotechnology, biomechanics and other advanced scientific territories have increasingly been updating the contemporary discussion of architecture. Popular media about technologies of life has educated a greater audience. The concept behind this is that an organism (not just the human one) is an extremely complicated system, a network of parallel lives, of simultaneously evolving organic systems. A human is partly animal and partly an array of bacteria, microbes and parasites. The notion of a new fragility is defined, not one caused by our weakness against the nature outside, but a fragility structured by the small natures inside our body, which keep it unstable and disturbed even though in balance.

At the same time we witness an ever-increasing medicalization of the human environment. Hygienic conditions become stricter and sanitary care is encouraged to almost extreme degrees. Architecture has always tried to provide a certain cell, detached from the environment in terms of temperature, exposure to elements of nature, wind, rain, but also dirt, microbes etc. To be more precise, architecture has been trying to protect the human from everything alive in the close periphery. The notion of organic fragility is a strongly established one, and it affects design and architecture. Architecture tries to strengthen our weak immune system and protects us from its enemies. But simultaneously, architecture is fascinated and formally inspired by all this biological paraphernalia and the way nature and life emerges and evolves.

\section{Denouncing digital Puritanism}

Innovative technology design research is already an established act and the use of digital tools can be considered as a given condition. Sometimes, though, strict obeying of tools, features and software capabilities creates often myopic and shortsighted design outcomes. The kind of projects produced under this trend, are sometimes much involved with an obviously controllable micro scale, a long way down the design procedure. This is the reason why there is already a general attempt for a reaction against the establishment of a so-called 
'digital rationalism', or even Puritanism, when it comes to the form-finding techniques and space's formal characteristics.

Denouncing of a so-called digital Puritanism promotes a broader and more creative approach of innovative design tools and advanced methodologies. It encourages a more poetic hue in architectural design, a hue that reveals a more intuitive and narrative manipulation of space. Architecture produced under this trend, resorts to a more narrative and plethoric documentation of an alternative, personal space, potentially evident and inhabitable. This space is perceived more through intuition than through proper decoding of a respectable, digitally coded design language.

\section{The rebirth of personal style}

This kind of architecture can equip space with personality, eccentricity and character. Inevitably, as a result of the design mechanism going personal and the tools being freely available to anyone and substantially easy to use, there is an evident tendency for decoration. A whole new baroque feeling has emerged in advanced architectural design projects. Decoration and ornament returns sometimes in a massive scale, even though sometimes cleverly disguised under the identities of 'differentiation and adaptation schemes and variation studies'. Nevertheless it is plethoric and exuberant ${ }^{10}$ rich in sensory and sensual stimuli. This new personal style is executed avoiding a graphic 'copy-paste' and any mimetic representation. On the contrary, what is suggested is an organic incorporation of decorative elements in a broader frame of morphological elaboration. Decorative complexity seems to be part of the newly defined attributes of architectural experiments and advanced, innovative design technologies.

\section{CONCLUSION}

Architectural community, educators, students, practitioners and thinkers are constantly flooded by new information and ever-increasing details about the immensely complicated event of space designing procedure. It may appear as necessary, therefore, to take a step back, so as to be able to receive and comprehend a broader sight of designing event. The surrounding world is a complex set of elements and so are lives of humans, therefore, our social behavior within the designed architectural space closely depends on decisions made by the architect. In this frame, technology offers all tools to essentially drain wisdom out of nature and inspire a new formal presence for the built 
environment ${ }^{11}$. There is, once more, a re-invented cultural role to be identified within young researchers' approaches to architecture. Some of their projects constitute intelligent, almost bodily incarnations of cultural and social needs and values, encouraging new versions of social life and interaction and leaving ever less room for skeptical approaches. The suggested shift of paradigm and the subsequent architecture seems to be able to reclaim the capacity to selfregulate itself confronting the massive evolution of its substantial design tools, thus, constituting a concise, holistic spatial event.

G. Broadbent, „The deep structures of architecture“, in Design in Architecture (London: Wiley and Sons, 1974).

R. Venturi, Complexity and Contradiction in Architecture (New York: The Museum of Modern Art, 2002).

M. Weinstock, The Architecture of Emergence: The Evolution of Form in Nature and Civilization (London: Wiley, 2010).

P. Cook, AD: Drawing: the motive force of architecture (Great Britain: Wiley, 2008). A. S. Bregman, Auditory Scene Analysis, The Perceptual Organization of Sound (Bradford Book, 1990). 
M. Weinstock, The Architecture of Emergence: The Evolution of Form in Nature and Civilization (London: Wiley, 2010).

M. Colletti, AD: Exuberance: new virtuosity in contemporary architecture (London: Wiley, 2010).

A. Tellios, Synecdoches: architecture, image, spatial representation (Thessaloniki: Epikentro, 2011).

Allen L., Borden I., N. O’ Hare and N. Spiller. Bartlett Designs: speculating with architecture. United Kingdom: Wiley, 2009.

Anestidis I., I. Siopidis and A, Tellios (superv.), Deterministic Chaos: Emerging natural structures, Diploma theoretical research. Thessaloniki: School of Architecture, Aristotle University of Thessaloniki, 2010-2011.

Aranda B. \& Lasch Ch. Tooling. New York: Princeton Architectural Press, 2006.

Benthien C. Skin: On the Cultural Border Between Self and World. New York: Columbia University Press,2002.

Bregman, A. S. Auditory Scene Analysis, The Perceptual Organization of Sound. Bradford Book, 1990.

Breton A. Manifestoes of Surrealism. The University of Michigan Press, 1924.

Broadbent G., 'The deep structures of architecture', in Design in Architecture. London: Wiley and Sons, 1974.

Charidis A., Tellios, A. (superv.), 'Spatial Cochleas', Design studio: 2S1 62, Spatial Investigations and the limits of design, School of Architecture, Aristotle University of Thessaloniki, 20102011. 
Colletti M. AD: Exuberance: new virtuosity in contemporary architecture. London: Wiley, 2010.

Cook P. AD: Drawing: the motive force of architecture. Great Britain: Wiley, 2008.

Cruz M. and Pike S. AD: Neoplasmatic Design. London: Wiley, 2008.

Davies, C. Key houses of the twentieth century. New York: WWNorton \& Co Inc, 2006.

Diller + Scofidio. Flesh. New York: Princeton Architectural Press, 1994.

Feuerstein G. Biomorphic Architecture: Human and Animal Forms in Architecture. Stuttgart and London: Edition Axel Menges, 2002.

Frazer J. An Evolutionary Architecture. London: Architectural Association, 1995.

Garcia M. AD: Architextiles, London: Wiley, 2006.

Glancey J. Nigel Coats: Body Buildings and City Scapes. London: Thames and Hudson, 1999.

Hensel M., Menges A. and Weinstock M. AD: Techniques and Technologies in Morphogenetic Design. London: Wiley, 2006.

Kelly K. Out of Control: Biology and Machines, Fourth Estate, 1994.

Levy S. Artificial Life: The Quest for a New Creation. London: Jonathan Cape, 1992.

Lynn G. Animate Form. New York: Princeton Architectural Press, 1999.

Macarthur J. The Butcher's Shop: Disgust in Picturesque Aesthetics and Architecture. USA: MIT press, 1996.

Mitchell W. City of Bits: Space, Place, and the Infobahn. USA: MIT press, 1996.

Oosterhuis K. Hyper bodies: Towards an E-motive Architecture. Basel, Switzerland: Birkhäuser, 2003.

Pallasmaa J. The eyes of the skin: Architecture and the Senses. Great Britain: Wiley, 2005.

Papalexopoulos, D. Digital Regionalism. Athens: Libro, 2009.

Papalexopoulos, D., Kalafati E. and Takis X. Zenetos. Digital Visions and Architecture. Athens: Libro, 2006.

Prestinenza Puglisi L. Hyper Architecture: Spaces in the Electronic Age. Switzerland: Birkhäuser, Basel, 1999.

Psaltis S., Tellios A. (superv.), 'Inhabiting fragile territories: a little story for a little house', Diploma design project, School of Architecture, Aristotle University of Thessaloniki, 20102011.

Sachs A. (ed.), Museum of Design Zurich, Nature Design: from inspiration to innovation. Baden: Lars Muller Publishers, 2007.

Sadler S. The situationist city. USA: MIT press, 1998.

Sheil B. AD: Design Through Making. London: Wiley, 2005.

Sheil B. AD: Protoarchitecture: Analogue and Digital Hybrids. London: Wiley, 2008.

Spiller N. Digital Architecture Now: a global survey of emerging talent. London: Thames \& Hudson, 2008.

Spiller N. Visionary Architecture: Blueprints of the Modern Imagination. London: Thames \& Hudson, 2006.

Tellios A. Synecdoches: architecture, image, spatial representation. Thessaloniki: Epikentro, 2011.

Tsakiridis G., Tellios A. (supev.), 'Birth ponds, in_vitro/arch', Design studio: 2 S1 62, Spatial Investigations and the limits of design, School of Architecture, Aristotle University of Thessaloniki, 2010-2011

Venturi, R. Complexity and Contradiction in Architecture. New York: The Museum of Modern Art, 2002.

Weinstock M. The Architecture of Emergence: The Evolution of Form in Nature and Civilization. London: Wiley, 2010.

The Calculations of La Sagrada Familia, Temple Expiatori Sagrada Familia, Archives and Documents, http://www.sagradafamilia.cat/sf-eng/docs_instit/pdf/estruct_03.pdf, 19 April 2012. 


\section{SLOŽENA PRIRODA POTENCIJALNIH BUDUĆNOSTI ARHITEKTURE}

\section{Anastasios Tellios}

Arhitektura se menja, u skladu sa inovacijama i tehnološkim dostignućima alatki i metodologija projektovanja. Međutim, istraživanje i definisanje prostora i dalje ostaje njen osnovni zadatak. Tehnologija koja je dostupna arhitektama je reviolucionalizovala upravljanje morfogenetskim postupcima kroz nove tehnike modeliranja, formalne spekulacije i njeno upotpunjivanje umetničkom intuicijom. Ohrabrila je arhitekte da eksperimentišu sa konstrukcijama i morfološkim atributima prirodnih sistema i organskim kao i neorganskim oblicima i ozbiljno je uticala na odgovarajuće prostorne predoge. Nove koncepcije, uvedene u arhitektonsku diskusiju i savremeno istraživanje vođeno projektovanjem sugerišu izuzetne primere prostornih uređenja, govore o potpuno novoj arhitektonskoj stvarnosti. Prilazom preko holističkog i interdisciplinarnog spektra i još uvek zatočena unutar Arhitektonskih fakulteta, ova nova arhitektura odmerava svoj budući potencijal i šanse za stvarnu primenu.

KLJUČNE REČI: PROJEKTOVANJE VOĐENO BIOLOGIJOM, PRIRODNA ADAPTACIJA, GENERATIVNA

ARHITEKTURA, PROSTORNO ISTRAŽIVANJE, ARHITEKTONKSI NARATIV, POJAVLJIVANJE

\section{PRIVREMENE UPOTREBE KAO SREDSTVA EKSPERIMENTALNOG URBANOG PLANIRANJA}

\section{Panu Lehtovuori, Sampo Ruoppila}

Savremeni ekonomski, društveni i kuturni trendovi podržavaju interes za privremene upotrebe nekretnina i urbanog prostora. Privremene upotrebe imaju eksperimentalni karakter u izgradnji , i saglasne su da imaju puno društvenih i komercijalnih koristi, uključujući kreiranje prostora i podršku zajedničkih praksi. Ovaj članak daje tipologiju društveno-prostornih uslova i ciljeva privremenih upotreba. Kada su projektovani i implementirani u gradske centralne oblasti, trenutno nedovoljno korišćene oblasti, ili oblasti koje gube svoj značaj, privremene upotrebe se shodno tome usklađuju radi intenziviziranja, početka i redefinisanja njihovih lokacija. Identifikovana su četiri pristupa koje su javne vlasti uzele da bi obuhvatile privremene upotrebe. To su: dosledan, na projektnoj bazi, centralističko-idealistički i pristup najboljih praksi. 